\title{
Nutraceuticals in reproduction of bulls and stallions
}

\section{Rubens Paes de Arruda ${ }^{1}$, Daniela Franco da Silva ${ }^{1}$, Maria Augusta Alonso ${ }^{1}$, André Furugen Cesar de Andrade ${ }^{1}$, Juliana Nascimento ${ }^{1}$, Andres Mejia Gallego ${ }^{1}$, Simone Maria Massami Kitamura Martins $^{1}$, Thaís Marques Granato ${ }^{1}$}

\footnotetext{
${ }^{1}$ Laboratory of Semen Biotechnology and Andrology, Department of Animal Reproduction, School of Veterinary Medicine and Animal Science, Universidade de São Paulo (USP), Pirassununga, SP, Brazil.
}

ABSTRACT - The industry has made available in the market a series of substances (nutraceuticals) which intent would be to optimize the use of nutrients in some metabolic paths, influencing positively reproductive performance in animals. However, the response to the use of nutraceuticals varies according to the animal. As the organism is highly complex and in order to achieve a perfect activity of the hypothalamic-pituitary-gonadal axis, an ideal interaction in molecular basis is needed, where the nutraceuticals can have their direct action. The aim of this study was to review the function and research results using the main nutraceuticals ( $\beta$ carotene, vitamin A, L-carnitine, omegas 3, 6 and 9 and Gamma-oryzanol) on reproductive characteristics of bulls and stallions.

Key Words: $\beta$ carotene, bull, gamma-oryzanol, L-carnitine, nutraceutics, omegas 3, 6, 9, stallion

\section{Nutracêuticos na reprodução de touros e garanhões}

\begin{abstract}
RESUMO - A indústria tem disponibilizado no mercado uma série de substâncias (nutracêuticos) com a intenção de otimizar a utilização de nutrientes em algumas vias metabólicas, influenciando positivamente o desempenho reprodutivo dos animais. No entanto, a resposta ao uso de nutracêuticos varia de acordo com o animal. Como o organismo é altamente complexo e, a fim de alcançar perfeita atividade do eixo hipotálamo-hipófise-gonadal, uma interação ideal na base molecular é necessária, onde os nutracêuticos podem ter sua ação direta. O objetivo neste estudo foi revisar a função e resultados de pesquisas usando os principais nutracêuticos ( $\beta$-caroteno, vitamina A, L-carnitina, ômegas 3, 6 e 9 e gama-orizanol) sobre as características reprodutivas de touros e garanhões.
\end{abstract}

Palavras-chave: $\beta$-caroteno, gama-orizanol, garanhões, L-carnitina, nutracêuticos, ômegas 3, 6, 9, touro

\section{Introduction}

Functional foods and nutraceuticals commonly have been considered synonyms, however functional foods is any healthy or fictional food claimed to have healthpromoting or disease preventing properties beyond the basic function of supplying nutrients, such as reduction of disease risk and maintenance of physical and menthal well being and consumed as part of the diet. Biologically active substances encountered in functional foods can be classified in groups as: probiotics and prebiotics, sulfured and nitrogen foods, pigments and vitamins, phenolic compounds, polyunsaturated fatty acids and fibers. In the other hand, nutraceuticals are food or part of the food that have benefits to health, including prevention and/or disease treatment. They can include isolated nutrients, diet supplements, genetic engineered products, herbal products and processed food (Moraes \& Colla, 2006).
Spermatogenesis, the processes of masculine gamete formation, which takes place within the testicles, more specifically in seminiferous tubules, demands a balanced function of all systems in the organism, knowing the sensitivity of the germinative epithelium. It is atablished that environmental factors can alter hormonal secretion and cellular differentiation in the testicles and maturation and transport in the epididymis. In face of adverse factors, especially nutritional, reproductive organs present degeneration and disturbances of different degrees and intensities, temporary or permanent, therefore determining a greater or lesser influence in the animal's fertility.

In Central Brazil, testicular degeneration is considered the greatest cause of low fertility in Bos taurus bulls raised extensively (Vale Filho, 1974). No doubt, it can be affirmed that among other environmental factors, the occurrence of food shortage of diverse natures, mainly during the dry months of the year, significantly cause the low performance 
of the animals. Food shortage considered as a complex can be proteic, energetic, mineral or vitamin in its origin.

Unfortunately, there is a great individual variation among stallions in sperm viability maintenance during cooled semen storage. For some stallions, even with adequate care during the whole procedure, sperm that survive cooling are insufficient to provide a sufficient number of viable sperm for artificial insemination (Arruda et al., 2009).

Nowadays, athletic performance is required from a great part of the stallions, which have an intense training regimen associated with semen collection/live cover schedule, leading to an increase in nutritional requirements. Thus, a nutritional program becomes mandatory, aiming an optimization of performance as athletes and stallions (Franceschini, 2003).

Bulls raised under tropical conditions, such as in Brazil, can present quantitative and qualitative semen characteristics variations, promoted among other causes by thermal stress, management practices, nutritional status and, the specially the amount and quality of pastures (Aurélio, 2008).

\section{$\beta$-carotene and vitamin $A$}

In the literature, one can find that $\beta$-carotene, provitamin A, acts beneficially in the organism in the same manner vitamin A does, although presenting specific physiological functions, being essential for the epithelial tissues functioning in reproductive organs (Arikan \& Rodway, 2000). $\beta$-carotene is found in extremely high concentrations in the bovine corpus luteum (CL) (O'Fallon \& Chew, 1984; Holt et al., 1995), causing the characteristic yellow color in the CL. Besides acting as a vitamin A precursor, there are evidences that $\beta$-carotene can be necessary for ideal steroid production, possibly acting as an antioxidant (Young et al., 1995). Moreover, several studies in dairy cattle couldn't demonstrate the effect of $\beta$-carotene supplementation in steroid hormone levels (Folman et al., 1979; Wang et al., 1982).

Studies performed in laboratory demonstrated that $\beta$-carotene stimulates progesterone production in luteal cells cultivated in vitro and that $\beta$-carotene concentration in culture media lowers during incubation, being more abrupt when cells are stimulated with LH and/or cAMP (Arikan \& Rodway, 1997,1998), suggesting that $\beta$-carotene is metabolized during the steroidogenic process.

Weiss et al. (1979) investigated the influence of $\beta$-carotene on some sperm characteristics in young bulls under a food regimen with shortage of this substance, but supplemented with vitamin A. After 27 weeks of the experiment, results showed that $\beta$-carotene deficiency provoked a reduction in sperm progressive motility and an increase in morphological alteration percentage of the head and citoplasmatic droplet in middle piece, that indicate retarded spermatogenesis and spermatic maturation disturbances in the epididymis.

Erb et al. (1947) found that young dairy bulls that received food with low vitamin A content had, besides weight loss and vision alteration, seizures, spermatogenesis decrease and testicular atrophy. In adult bulls, no sterility cases were found, but vitamin A deficiency caused low fertilizing capacity, as a consequence of bad semen quality. Bratton et al. (1948) submitted 6 bulls to a deprived pro vitamin A food for 21 months. In the end of the experiment three bulls presented sperm motility decrease and increase in abnormal sperm shapes. Histologically, germinative epithelium of seminiferous tubules presented degeneration signs and few cells in the tubules lumen. Schmidt (1953) designed an experiment using white and red carrots in bulls feeding, maintaining basic food with normal carotenoids levels. After analyzing 124 seminal samples from 6 treated bulls, bulls supplemented with red carrots presented $7 \%$ higher values for volume, concentration and total sperm numbers compared with bulls receiving white carrots. The author attributed this superiority to $\beta$-carotene influence.

With the purpose of evaluating the effects of vitamin A deficiency on bull's reproductive characteristics, Rode et al. (1995) delineated an experiment where Hereford bulls (16 months of age, $462 \mathrm{~kg}$ average body weight) were used. They were fed with a diet rich in concentrated with (+VIT) or without (-VIT) vitamin A supplement until hypovitaminosis A was apparent (28 and 32 weeks in years 1 and 2, respectively). Half of the bulls from each treatment were slaughtered and the remaining where re-fed with vitamin A. Retinol plasmatic concentration in -VIT bulls reached their lowest value in 25 weeks. In year 1 , the proportion of sperm with progressive motility was lower in-VIT bulls after 17 weeks, but was similar to the +VIT bulls after receiving Vitamin A again. The proportion of sperm with primary morphological defects seemed higher in-VIT bulls compared with +VIT bulls in weeks 26 and 24 in year 1 and 2, respectively. The incidence of these defects decreased in -VIT bulls after being re-fed with Vitamin A in weeks 8 and 12. Vitamin A hypovitaminosis led to a decrease in testicles weight, daily sperm output, and epididymal sperm storage, but did not affect daily weight gain. Prolonged vitamin A diet deficiency was detrimental to sperm quality and production in the absence of other clinical signs. However, under practical feeding conditions, diets leading to marginal vitamin A deficiency 
or relative ingestion absence for a short period probably would have minimal effect on spermatogenesis.

\section{L-carnitine}

In a very interesting introduction, Stradaioli et al. (2000) describe that among the factors that can affect semen quality and spermatozoa storage (Pickett, 1993; Bedford et al., 1995; Magistrini et al., 1996), seminal plasma constituents must be considered, which reflect changes in epididymis and accessory sexual gland secretions (Setchell et al., 1994). Stallion sexual gland markers include carnitine which has only been found in epididymal plasma (Magistrini et al., 1995a,b) and represents nearly all the carnitine available in seminal plasma, as observed in other mammals (Jeulin \& Lewin, 1996). Carnitine is taken from the blood stream and then released in epididymal lumen by active epithelial pumps (Brooks, 1980), which are regulated by androgens in rat (Cooper et al., 1986a) and monkey (Cooper et al., 1986b). Carnitine is best acknowledged as a key compound in energyproducing processes since it modulates mitochondrial fatty acid oxidation. To accomplish this role, carnitine needs the concerted action of a discrete number of membrane-bound, carnitine-dependent, long-chain acyltransferases, also known as carnitine palmitoyltransferases (CPTI and CPTII), and acyl-carnitine translocase (Bieber, 1988).

Spermatozoa increase their carnitine content and progressive motility during passage through the epididymis where carnitine is esterified within sperm cells in acetylcarnitine (Casillas, 1973). Acetylated l-carnitine is the major form of acylcarnitine in mammal tissues (Bieber et al., 1982).

In this context, another important action of carnitine is to modulate the intramitochondrial acetyl-CoA/free CoA ratio via carnitine acetyltransferase (CAT) (Uziel et al., 1988; Abdel-Aleem et al., 1995), a mitochondrial enzyme able to catalyze the reversible transfer of the acetyl-unit from CoA to carnitine (Bieber et al., 1982).

Since elevated levels of mitochondrial acetyl-CoA cause the inhibition of a number of key enzymes of such oxidative pathways as pyruvate dehydrogenase and 3-keto-acylCoA thiolase, a reduction of acetyl-CoA by carnitine may relieve such an inhibitory effect (Wang et al., 1991; AbdelAleem et al., 1995; Jeulin an\& Lewin, 1996). Both extra and intracellular acetylcarnitine provide readily available acetyl groups for spermatozoa motility (Milkowsky et al., 1976; Bruns \& Casillas, 1990). In mature spermatozoa, high intracellular L-carnitine concentrations increase the utilization of pyruvate and lactate (Carter et al., 1980; Jones \& Murdoch, 1996), thus holding the maximal "acetylationstate" of carnitine.
In human beings, seminal L-carnitine content is correlated with spermatozoa count and progressive motility (Menchini-Fabris et al., 1984; Borman et al., 1989) and a reduction of the acetylcarnitine/l-carnitine ratio has been observed in asthenospermic patients (Golan et al., 1984; Bartellini et al., 1987). Moreover, significant reduction of seminal carnitine concentrations has been reported in azoospermic patients affected by bilateral agenesis of the vas deferens and epididymal obstruction (Menchini-Fabris et al., 1984; Casano et al., 1987), as well as during severe testicular failures (Lewin et al., 1981). Recently, a reduction of seminal plasma carnitine has been reported in infertile men (Zöpfgen et al., 2000). The positive correlation observed among seminal parameters and seminal carnitine concentration allows proposing carnitine as a "good quality" semen marker (Menchini-Fabris et al., 1984).

L-carnitine is of major significance, because when administered in diet, acts on long chain fatty acid transport inside the mitochondria for beta oxidation and synthesis of phosphates rich in energy, optimizing energy and mitochondrial production, thus improving sperm motility and survival pre and post freezing (Franceschini, 2003).

The reproductive characteristics and seminal carnitine and acetylcarnitine content as well as carnitine acetyltransferase activity of young Maremmano stallions ( $n$ D 25) are reported (Stradaioli et al., 2000). The stallions were subjected to semen collections in November and January; in each trial two ejaculates were collected $1 \mathrm{~h}$ apart. The total motile morphologically normal spermatozoa (TMMNS) and the progressively motile spermatozoa at collection and during storage at $+4^{\circ} \mathrm{C}$ were evaluated. Seminal L-carnitine (LC), acetylcarnitine (AC), pyruvate and lactate were measured using spectrophotometric methods, whereas carnitine acetyltransferase activity was measured by radioenzymatic methods. Significant differences $(\mathrm{P}<0.001)$ were observed between the first and second ejaculates for sperm count $(0.249 \pm 0.025$ versus $\left.0.133 \pm 0.014 \times 10^{9} / \mathrm{ml}\right)$, total number spermatozoa by ejaculate $\left(12.81 \pm 1.23\right.$ versus $\left.6.36 \pm 0.77 \times 10^{9}\right)$, progressively motile spermatozoa (48.6 \pm 3.0 versus $52.6 \pm 3.0 \%$ ) and TMMNS ( $3.35 \pm 0.50$ versus $\left.2.02 \pm 0.37 \times 10^{9}\right)$. In the raw semen the LC and $\mathrm{AC}$ were significantly higher in the first ejaculate than in the second $(\mathrm{P}<0.001)$, whereas, pyruvate and pyruvate/ lactate ratio were higher in the second ejaculate $(\mathrm{P}<0.05)$. Seminal plasma AC and LC concentrations were higher in the first ejaculate $(\mathrm{P}<0.001)$. The pyruvate/lactate ratio was higher in the second ejaculate $(\mathrm{P}<0.05)$. Both raw semen and seminal plasma LC and AC concentrations were positively correlated with spermatozoa concentration $(\mathrm{P}<0.01)$; in raw 
semen AC was also correlated to TMMNS $(\mathrm{P}<0.01)$. Lactate levels of raw semen were correlated to progressively motile spermatozoa after storage $(\mathrm{P}<0.01)$. In the second ejaculate, significant correlations were also observed among AC/LC ratio in raw semen and progressively motile spermatozoa after 48 and 72 h of refrigeration. Furthermore, AC levels were correlated to lactate concentration. The positive correlation between LC, AC and spermatozoa concentration and between AC and TMMNS indicated carnitine as potential semen quality marker. Moreover, the correlation between AC/LC ratio and progressive spermatozoa motility after refrigeration, suggested that carnitine may contribute towards improving the maintenance of spermatozoa viability during in vitro storage.

To improve performance and reproductive indexes, a study was carried out to assess the effects of L-carnitine on reproductive parameters of pure Arabian horses (Rosas Filho et al., 2001). Horses were randomly divided into blocks by semen quality (good, medium, bad). After this, the blocks were divided in two groups. The first group was classified as control and the other one as treated. The second group received a diet containing $10 \mathrm{~g}$ of L-carnitine for a period of 90 days. Two weekly semen collections were performed to evaluate gel free volume, progressive motility, spermatic concentration, total sperm; spermatic morphology (major and minor defects) and once weekly testicular measurements were made. The results showed that there were no statistical differences $(\mathrm{P}>0.05)$ in the following semen parameters: gel free volume, progressive motility, spermatic concentration, total concentration, spermatic morphology (except minor defects, $\mathrm{P}<0.05$ ) and testicular measurements.

Lima (2003) performed an experiment aiming to evaluate the influence of L-carnitine oral ingestion on stallion's cryopreserved semen and its possible effect on total sperm per ejaculate, total and progressive motility, sperm velocity, membrane integrity and thermoresistance test (TRT). Means and standard deviations of progressive motility, linearity, path velocity, progressive velocity and curvilinear velocity were significantly higher for control group (TO) comparing with treated group (T1) before TRT was performed. After the TRT, means and standard deviations were significantly higher for TO for path velocity and progressive velocity; there was no significant difference among groups after TRT was conducted for progressive motility, linearity and curvilinear velocity. After TRT, there was an abrupt decrease in progressive motility, linearity, path velocity, progressive velocity and curvilinear velocity for the control group (TO) compared with the treated group (T1). According to the authors, results lead to the conclusion that L-carnitine can, in some circumstances, be an important therapeutic tool for stallion's sperm quality improvement.

L-carnitine has an important role in diet administration and, among others, has the function of influencing the transport of long chain fatty acids inside mitochondria for beta oxidation and energy-rich phosphate, optimizing mitochondrial and energy production, thus improving motility and survival of spermatozoa pre and post freezing. Likewise, Franceschini (2003) designed and experiment to verify the effect of L-carnitine supplementation on stallion's post freezing semen quality. Furthermore, evaluation of mitochondrial activity of sperm after freezing and thawing was performed. Results indicated that L-carnitine supplementation had a positive effect on mitochondrial activity, promoting reduction in the amount of sperm with inactive mitochondria. Besides causing an improvement in cryopreserved sperm total motility, possibly due to an optimization of their energy metabolism.

\section{Omegas 3,6 and 9}

Differences in the ability of sperm from various animals to resist cold shock appear to be related to their sperm membrane lipid composition (Parks \& Lynch, 1982; Brinsko et al., 2005). The lipid composition of sperm membranes not only influences the response of sperm to cooling and freezing, but also plays a major role in the physiologic changes leading to fertilization (Langlais \& Roberts, 1985; Ladha, 1998).

Semen from all domestic species contains high levels of polyunsaturated fatty acids (PUFA), in particular, docosahexaenoic acid (DHA; 22:6 n-3, an omega-3 fatty acid) and docosapentaenoic acid (DPA; 22:5 n-6, an omega6 fatty acid). The semen of boars has very high levels of DPA and the semen lipid profile of stallions is similar to that of the boar (Parks \& Lynch, 1982). Studies in the boar have shown that a high DHA to DPA ratio in semen results in enhanced fertility, while higher levels of DPA relative to DHA results in reduced fertility (Penny et al., 2000; Maldjian et al., 2003; Brinsko et al., 2005). In asthenozoospermic men, the level of DHA in seminal plasma as well as the ratio of omega- 3 to omega- 6 fatty acids in sperm was found to be lower than in normozoospermic men (Conquer et al., 1999). Since animals are unable to synthesize PUFAs from saturated or monounsaturated fatty acids, they must acquire them from precursor PUFAs in their diet. The transfer of dietary PUFAs to sperm has been shown to be effective in a number of species (Drokin et al., 1999; Conquer et al., 2000; Penny et al., 2000). Unfortunately, most proprietary horse feeds are very high in precursors for omega- 6 fatty acids while the precursors for omega-3 fatty acids, such as DHA, are very 
low. Brinsko et al. (2005) studied the effects of a DHA rich nutraceutical (omega 3) on fresh, cooled and frozen semen quality. Stallions were randomly assigned to one of two treatment groups ( $n=4$ per group). Stallions were fed their normal diet (control) or their normal diet top-dressed with 250 g of a DHA-enriched nutraceutical. Feeding trials lasted for 14 week, after which a 14-week washout period was allowed and the treatment groups were reversed for another 14 week feeding trial. Feeding the nutraceutical resulted in a three-fold increase in semen DHA levels and $50 \%$ increase in the ratio of DHA to DPA in semen. Sperm motion characteristics in fresh semen were unaffected by treatment. After $24 \mathrm{~h}$ of cooled semen storage in an Equitainer $^{\mathrm{TM}}$, total and progressive motility did not differ between treatment groups, but sperm from stallions fed the nutraceutical exhibited higher velocity and straighter projector $(\mathrm{P}<0.05)$. After $48 \mathrm{~h}$ of cooled storage, increases in the percentages of sperm exhibiting total motility $(\mathrm{P}=0.07)$, progressive motility $(\mathrm{P}=0.06)$ and rapid motility $(\mathrm{P}=0.04)$, were observed when stallions were being fed the nutraceutical. For a subset of four stallions, whose progressive sperm motility was $<40 \%$ after 24 h of cooled storage when fed the control diet, feeding the nutraceutical resulted in improvements in mean progressive motility of sperm after $24 \mathrm{~h}(\mathrm{P}=0.10)$ and $48 \mathrm{~h}(\mathrm{P}=0.03)$ of storage. Feeding the nutraceutical resulted in similar improvements in motion characteristics being observed in frozen-thawed semen. While it appears that feeding the nutraceutical may improve the motion characteristics of cool-stored stallion semen, it may be most beneficial for stallions of marginal fertility whose sperm do not tolerate the rigors of cooling and storage. The nutraceutical also appeared to improve the freezability of semen. More dramatic improvements in semen quality may be observed if modifications in the main fat content of the diet are incorporated with the DHA supplement.

Elhordoy et al. (2008) investigated the action of the polyunsaturated fatty acids (PUFAs), in particular decosahexanoic acid (DHA; 22:6 n-3, omega-3 fatty acid), on the quality of fresh, cooled and frozen stallion semen. Six stallions were randomly assigned to two treatment groups ( $n=3$ per group) and were kept under the same management conditions. Stallions of one group (group A) were fed $30 \mathrm{~g}$ of DHA per day for 80 days, while the others (group B) did not receive any supplementation. The treatment groups were then reversed, with the group B fed with $30 \mathrm{~g}$ of DHA and group A serving as a control. Both groups were subjected to a washout period before the second stage of this switch-back study. This period was established to allow DHA levels of treated stallions to return to pretreatment levels. Preliminary results show that treated stallions experienced an increase in total spermatozoal number per ejaculate $(\mathrm{P}<0.05)$, motility $(\mathrm{P}<0.05)$, and a reduced percentage of dead and abnormal spermatozoa $(\mathrm{P}<0.05)$, especially in the acrosome and mid-piece abnormalities $(\mathrm{P}<0.001)$, in comparison with the control treatment. Mean percentage of progressively motile (PM) spermatozoa improved in some of the stallions after $48 \mathrm{~h}$ of cooled-semen storage and after semen cryopreservation. The greatest increase in these parameters was shown in PM of the stallions with initial poor quality semen. Moreover, the most significant morphological improvement was detected in the stallions with the poorest initial morphology, similarly to the stallions with the lowest PM following preservation. These data suggest that dietary DHA supplementation in stallions can increase daily spermatozoa output, and quality of cooled and cryopreserved semen, possibly due to an increase sperm plasma membrane DHA content. The effect was magnified in those stallions with initially poor-quality ejaculates. More research is needed to substantiate these findings in a larger group of stallions.

\section{Gamma-oryzanol}

Gamma-oryzanol was discovered in rice oil in 1954 by Kaneco and Tsuchiya, in Japan (Gonzaga, 2008) and initially described as the only component, but later studies revealed that the substance is far from being simple, and the contrary, it is a variety of ferulate esters called $\alpha, \beta$ and $\gamma$-orizanol (Scavariello \& Arellano, 1988). Gama-oryzanol has received most attention owing to health beneficial properties, such as plasmatic cholesterol reduction, platelet aggregation inhibition, reduction in hepatic cholesterol biosynthesis, reduction in cholesterol absorption and increase in fecal biliary salts excretion. It is used in pharmaceutical and cosmetic industry, as well as food additive due to antioxidant properties (Juliano et al., 2005; Gonzaga, 2008).

Gama-oryzanol components were isolated and identified by Xu \& Godber (1999), as $\Delta$-estigmastenol ferulate, estigmasterol ferulate, cycloarterol ferulate 24-metilen cicloarterol ferulate, $\Delta$-campestenil ferulato, campesteril ferulato $\Delta$-sitostenil ferulato, sitosteril ferulato, campestanil ferulato e sitostanil ferulato.

Fry et al. (1997) tested oral supplementaion efficiency (500 mg/day) of gamma-oryzanol in bodybuilder men. No significant differences were found in levels of circulating hormones (testosterone, cortisol, estradiol, GH, insulin, beta-endorphin), minerals (calcium and magnesium), albumin or blood lipids. Results showed that oral supplementation with $500 \mathrm{mg} / \mathrm{kg}$ of gamma-oryzanol during 9 weeks did not 
interfere with physical performance or physiological parameters observed.

With the objective of evaluating the effects of dietary supplementation with Gamma-Oryzanol (GO) on seminal characteristics of stallions (Raphael et al., 2006), six lighthorse stallions were split in two groups and supplemented for 60 days. The control group received $150 \mathrm{~mL}$ of soy oil, and the treatment group received $150 \mathrm{~mL}$ of rice oil containing 1,1\% of GO (Gamahorse ${ }^{\circledR}$ 3).Volume, concentration and morphology were evaluated. Sperm membrane integrity was evaluated using the hypoosmotic swelling test (HOS). No effect of GO supplementation was detected on reproductive characteristics. In another study, Arlas et al. (2008) also evaluated the effects of supplementary feeding of stallions with commercial rice oil (gamma oryzanol) (GamaHorse, HT Nutri ${ }^{\circledR}$, Brazil) on sperm parameters. Four stallions with ages ranging between 6 and 30 years were used. Animals were similarly managed for 190 days during the trial. The experiment was divided in three periods: pretreatment (PT) - 30 days to stabilize sperm reserves; treatment (TR)—80 days of supplementation with $200 \mathrm{~mL}$ rice oil containing $34 \%$ linoleic acid, $1 \%$ linolenic acid, $1 \%$ gamma oryzanol and vitamin E; control (CN)—80 days without rice oil supplementation. Semen evaluations were performed immediately after collection: volume, concentration, total motility, hypo-osmotic test (HOST) evaluating functionality, carboxyfluorescein diacetate/ propidium iodide (CFDA/PI) evaluating membrane integrity and total antioxidant potential (TRAP). A blood sample was obtained each 15 days to measure plasma testosterone and estradiol. The supplementation with rice oil increased concentration $(\mathrm{P}<0.01)\left(\mathrm{TR}: 226 \times 10^{6} \mathrm{~mL}^{-1}\right.$; $\mathrm{CN}$ : $\left.172 \times 10^{6} \mathrm{~mL}^{-1}\right)$, total motility ( $\left.<0.01\right)$ (TR: 59\%; CN: 42\%), HOST $(\mathrm{P}<0.02)$ (TR: 73\%; CN: 69\%) and TRAP $(\mathrm{P}<0.01)$ (TR: $1.9 \mathrm{nmol}$ Trolox/mg of protein; CN: $0.98 \mathrm{nmol}$ Trolox/mg of protein). No differences between periods of TR and CN were observed in volume, membrane integrity, testosterone or estradiol. The authors suggest that oral supplementation with the commercial rice oil containing PUFA and gammaoryzanol increased the total antioxidant potential of the semen. In addition, higher membrane functionality and motility was detected, possibly due to antioxidant protection preventing lipid peroxidation of sperm membranes or attributable to improved membrane fluidity.

\section{Commercial nutraceuticals}

With the purpose of investigating the effects of the commercial nutraceutical, Promater ${ }^{\circledR}$, in body weight, semen, libido and hormones (testosterone and cortisol) in Nelore Bulls, Aurélio (2008) used two groups of ten Nelore bulls, aging between 30 and 36 months. Group 1 (G1) was control and Group 2 (G2) received $20 \mathrm{ml} /$ animal/day of the product, during 70 days. Body weight, blood samples for testosterone and cortisol measurements and semen collection using eletroejaculation were obtained in days zero (D0), 35 (D35) and 70 (D70) in the two groups. Libido tests were conducted seven days before each collection (days -7, 28 and 63). There was difference $(\mathrm{P}<0.01)$ among collection days $\mathrm{D} 70=33.28 \mathrm{~cm}$, in relation to $\mathrm{D} 0=32.30 \mathrm{~cm}$ and $\mathrm{D} 35=32.18 \mathrm{~cm}$ in scrotal perimeter. There was difference in body weight $(\mathrm{P}<0.01)$ among days $(0,35 \mathrm{e} 70)$ with means of $424,30 \mathrm{~kg}$, $480,70 \mathrm{~kg}$ and 502, $60 \mathrm{~kg}$, respectively. There was no difference among groups referring to libido, seminal aspects, cortisol and testosterone. The results demonstrated that nutraceutical supplementation did not lead to an improvement in evaluated parameters.

\section{Final Considerations}

The industry, in general, has made available in the market a series of substances (nutraceuticals) that would supposedly optimize the use of nutrients in some metabolic paths, influencing positively the animal's athletic and reproductive performance.

However, the response to nutraceuticals use varies according to each individual, taking the breed, age, function, environmental and nutritional factors, etc in account. The organism is highly complex and, in order to possess a perfect functioning of hypothalamic pituitary gonadal axis, there is a need of perfect interactions in molecular basis. Nutraceuticals might be directly associated in these aspects. Therefore, the response to nutraceuticals utilization should be more efficient to one than other individual. Hence, a clinical and technical knowledge is essential for supplementing only when needed.

Further studies are needed to evaluate the real benefits from nutraceuticals supplementation as the experiments have small number of animals and results have low repeatability.

\section{References}

ABDEL-ALEEM, S.; SAVED-AHMED, M.; NADA, M.A. et al. Stimulation of non-oxidative glucose utilization by l-carnitine in isolated myocytes. Journal of Molecular and Cellular Cardiology, v.27, p.2465-2472, 1995.

ARIKAN, S.; RODWAY, R.G. The effect of beta-carotene either in organic solvent or as HDL on progesterone production by bovine luteal cells. Journal of Reproduction and Fertility, v.19, p.64, 1997 (abstr.)

ARIKAN, S.; RODWAY, R.G. Uptake and depletion of beta-carotene by bovine corpus luteum cells. In: BRITISH SOCIETY OF 
ANIMAL SCIENCE, 190., 1998, Ireland. Proceedings... Ireland: British Society of Animal Science., 1998. p.190.

ARIKAN, S; RODWAY, R.G. Effect of cyclodextrin-encapsulated $\beta$-carotene on progesterone production by bovine luteal cells. Animal Reproduction Science, v.64, p.149-160, 2000.

ARLAS, T.R.; PEDERZOLLI, C.D.; TERRACIANO, P.B. et al. Sperm quality is improved feeding stallions with a Rice oil supplement. Animal Reproduction Science, v.107, p.306, 2008.

ARRUDA, R.P.; ANDRADE, A.F.C.; CELEGHINI, E.C.C. et al. Manipulação e uso do sêmen transportado refrigerado de garanhões. In: SIMPÓSIO DE EQÜIDEOCULTURA - SIMEQ, 2., 2009, Viçosa, MG. Anais... Viçosa, MG: Universidade Federal de Viçosa, 2009. p.111-131.

AURÉLIO, P.T.F. Avaliação andrológica, libido e hormônios em touros nelore Bos Taurus indicus suplementados com nutracêutico. 2008. 76f. Dissertação (Mestrado em Ciência Animal) - Universidade do Oeste Paulista, Presidente Prudente.

BARTELLINI, M.; CANALE, D.; IZZO, P.L. et al. L-carnitine and acetylcarnitine in human sperm with normal and reduced motility. Acta Europaea Fertilitatis, v.18, p.29-31, 1987.

BEDFORD, S.J.; GRAHAM, J.K.; AMANN, R.P. et al. Use of two freezing extenders to cool stallion spermatozoa to $5^{\circ} \mathrm{C}$ with and without seminal plasma. Theriogenology, v.43, p.939953, 1995.

BIEBER, L.L. Carnitine. Annual Review of Biochemistry, v.57, p.261-283, 1988.

BIEBER, L.L.; EMAUS, R.; VALKNER, K. et al. Possible functions of short-chain and medium-chain carnitine acyltransferases. Federation Proceedings, v.41, p.2858-2862, 1982.

BORMAN, M.S.; du TOIT, D.; OTTO, B. et al. Seminal carnitine, epididymal function and spermatozoal motility. South African Medical Journal, v.75, p.20-21, 1989

BRATTON, R.W.; SALISBURY, G.W.; TANABE, T. et al. Breeding behavior, spermatogenesis, and semen production of mature dairy bulls fed rations low in carotene. Journal of Dairy Science, v.31, p.779-791, 1948

BRINSKO, S.T.; VARNER, D.D.; LOVE, C.C. et al. Effect of feeding a DHA-enriched nutriceutical on the quality of fresh, cooled and frozen stallion semen. Theriogenology, v.63, p.15191527, 2005.

BROOKS, D.E. Carnitine in the male reproductive tract and its relation to the metabolism of the epididymis and spermatozoa. In: McGARRY, J.D.; FRENKEL, R.A. (Eds.) Carnitine biosynthesis metabolism and function. Academic Press: New York, 1980. p.219-235.

BRUNS, K.A.; CASILLAS, E.R. Partial purification and characterisation of an acetylcarnitine hydrolase from bovine epididymal spermatozoa. Archives of Biochemistry and Biophysics, v.277, p.1-7, 1990.

CARTER, A.L; STRATMAN, F.W; HUTSON, S.M.; LARDY, H.A. The role of carnitine and its esters in sperm metabolism. In: McGARRY, J.D.; FRENKEL, R.A. (Eds.) Carnitine biosynthesis metabolism and function. New York: Academic Press, 1980. p.251-269.

CASANO, R.; ORLANDO, C.; CALDINI, A.L. et al. Simultaneous measurement of seminal l-carnitine, a,1-4-glucosidase, and glycerylphophorylcholine in azoospermic and oligozoospermic patients. Fertility and Sterility, v.47, p.324-328, 1987

CASILLAS, E.R. Accumulation of carnitine by bovine spermatozoa during maturation in the epididymis. Journal of Biological Chemistry, v.248, p.8227-8232, 1973.

CONQUER, J.A.; MARTIN, J.B.; TUMMON, I. et al. Fatty acid analysis of blood, serum, seminal plasma, and spermatozoa of normozoospermic vs. asthenozoospermic males. Lipids, v.34, p.793-799, 1999

CONQUER, J.A.; MARTIN, J.B.; TUMMON, I. et al. Effect of DHA supplementation on DHA status and sperm motility in asthenozoospermic males. Lipids, v.35, p.149-154, 2000.
COOPER, T.G.; GUDERMANN, T.W.; YEUNG, C.H. Characteristics of the transport of carnitine into the cauda epididymis of the rat as ascertained by luminal perfusion in vitro. International Journal of Andrology, v.9, p.348-358, 1986a.

COOPER, T.G.; YEUNG, C.H.; WEINBAUER, G.F. Transport of carnitine by the epididymis of the cynomolgus macaque (Macaca fascicularis). Journal of Reproduction and Fertility, v.77, p.297-301, 1986b

DROKIN, S.I.; VAISBERG, T.N.; KOPEIKA, E.F. et al. Effect of cryopreservation on lipids and some physiological features of spermatozoa from rams pastured in highlands and in valleys. Cytobios, v.100, p.27-36, 1999.

ELHORDOY, D.M.; CAZALES, N.; COSTA, G. et al. Effect of dietary supplementation with DHA on the quality of fresh, cooled and frozen stallion semen. Animal Reproduction Science, v.107, p.319, 2008.

ERB, R.E.; ANDREWS, F.N.; HAUGE, S.M. et al. Observations on vitamin A deficiency in young dairy bulls. Journal of Dairy Science, v.30, p 687-702, 1947.

FOLMAN, Y.; ASCARELLI, L.; HERZ, Z. et al. Fertility of dairy heifers given a commercial diet free of $\beta$-carotene. British Journal of Nutrition, v.41, p.353-359, 1979.

FRANCESCHINI, G.C.S. Efeito da adição dietética de L-carnitina sobre a atividade mitocondrial dos espermatozóides criopreservados de garanhões. 2003. 58f. Dissertação (Mestrado em Medicina Veterinária) - Faculdade de Ciências Agrárias e Veterinárias/Universidade Estadual Paulista, Jaboticabal.

FRY, A.C.; BONNER, E.; LEWIS, D.L. et al. The effects of gammaoryzanol supplementation during resistence exercise training. International Journal of Sport Nutrition, v.7, p.318-329, 1997.

GOLAN, R.; WEISSENBERG, R.; LEWIN, L.M. Carnitine and acetylcarnitine in motile and immotile human spermatozoa. International Journal of Andrology, v.7, p.484-494, 1984.

GONZAGA, I.V.F. Supplementation with rice bran oil semirefined with high level of gamma-oryzanol in stallion's diets. [Suplementação com óleo de farelo de arroz semi-refinado rico em gama-orizanol na dieta de garanhões]. 2008. 87f. Dissertação (Mestrado em Medicina Veterinária) - Faculdade de Medicina Veterinária e Zootecnia, Universidade de São Paulo, Pirassununga.

HOLT, A.J.; RODWAY, R.G.; FINDLAY, J.B.C. et al. Studies on $\beta$-carotene in bovine corpus luteum, Journal of Reproduction and Fertility, v.15, p.46-47, 1995 (abstr.).

JEULIN, C.; LEWIN, L.M. Role of free l-carnitine and acetylcarnitine in postgonadal maturation of mammalian spermatozoa. Human Reproduction Update, v.2, p.87-102, 1996.

JONES, R.C.; MURDOCH, R.N. Regulation of the motility and metabolism of spermatozoa for storage in the epididymis of eutherian and marsupial mammals. Reproduction, Fertility and Development, v.8, p.553-568, 1996.

JUliAnO, C.; COSSU, M.; ALAMANNI, M.C. et al. Antioxidant activity of gamma-oryzarol: mechanism of action and its effect on oxidative stability of pharmaceutical oil. International Journal of Pharmaceutics, v.299, p.146-154, 2005.

LADHA, S. Lipid heterogeneity and membrane fluidity in a highly polarized cell, the mammalian spermatozoon. Journal of Membrane Biology, v.165, p.1-10, 1998.

LANGLAIS, J.; ROBERTS, D. A molecular membrane model of capacitation and the acrosome reaction of mammalian spermatozoa. Gamete Research; v.12, p.183-224, 1985.

LEWIN, L.M.; PACE SHALEV, D.; WEISSENBERG, R. et al. Carnitine and acylcarnitines in semen from azoospermic patients. Fertility and Sterility, v.36, p.214-218, 1981.

LIMA, M.M. Influência da suplementação oral com L-carnitina na qualidade do sêmen criopreservado de garanhões. 2003. 61f. Dissertação (Mestrado em Medicina 
Veterinária) - Faculdade de Ciências Agrárias e Veterinárias/ Universidade Estadual Paulista, Jaboticabal.

MAGISTRINI, M.; SEGUIN, F.; BEAU, P. et al. 1H nuclear magnetic resonance analysis of stallion genital tract fluids and seminal plasma: contribution of the accessory sex glands to the ejaculate. Biology of Reproduction, v.1, p.599-607, 1995a (monograph)

MAGISTRINI, M.; McDONNEL, S.M.; SEGUIN, F. et al. Analysis of sex gland markers in equine seminal plasma of in copula and ex copula-induced ejaculates: quantification by magnetic resonance spectroscopy. In: INTERNATIONAL WORKSHOP ON ERECTION AND EJACULATION IN HORSES AND MEN, 2. 1995, Mount Joy. Proceedings... Mount Joy: 1995b, p.35-37.

MAGISTRINI, M.; VIDAMENT, M.; CLEMENT, F. et al. Fertility prediction in stallions. Animal Reproduction Science, v.42, p.181-188, 1996.

MALDJIAN, A.; PENNY, P.C.; NOBLE, R.C. Docosohexaenoic acid-rich marine oils and improved reproductive efficiency in pigs. In: De VRIESE, S.R.; CHRISTOPHE, A.B. (Eds.) Male fertility and lipid metabolism. Champaign: AOCS Press; 2003. p.60-72.

MENCHINI-FABRIS, G.F.; CANALE, D.; IZZO, P.L. et al. Free lcarnitine in human semen: its variability in different andrologic pathologies. Fertility and Sterility, v.42, p.263-267, 1984.

MILKOWSKY, A.L.; BABCOCK, D.F.; LARDY, H.A. Activation of bovine epididymal sperm respiration by caffeine: its transient nature and relationship to utilization of acetylcarnitine. Archives of Biochemistry and Biophysics, v.176, p.250255, 1976.

MORAES, F.P.; COLLA, L.M. Alimentos funcionais e nutracêuticos definições, legislação e benefícios à saúde. Revista Eletrônica de Farmácia, v.3, n.2, p.109-122, 2006.

O’FALLON, J.V.; CHEW, B.P. The subcellular distribution of $\beta$ carotene in bovine corpus luteum. In: PROCEEDINGS OF THE SOCIETY FOR EXPERIMENTAL BIOLOGY AND MEDICINE, 177., 1984, New York. Proceedings... New York: Society for Experimental Biology and Medicine, 1984. p.406-411.

PARKS, J.E.; LYNCH, D.V. Lipid composition and thermotrophic phase behavior of boar, bull, stallion, and rooster sperm membranes. Cryobiology, v.29, p.255-266, 1992.

PENNY, P.C.; MALDJIAN, A.; NOBLE, R.C. An enhancement of boar fertility and reproductive performance. In: INTERNATIONAL CONGRESS ON ANIMAL REPRODUCTION, 14., 2000, Stockolm. Proceedings... Stockolm: Organization International Committee for Animal Recording, 2000. p.109.

PICKETT, B.W. Factors affecting sperm production and sperm output. In: McKINNON, A.O.; VOSS, J.L. (Eds.) Equine reproduction. Philadelphia: Lea \& Febiger, 1993. p.689-704.

RAPHAEL, C.F.; GOBESSO, A.A.O.; ANDRADE, A.F.C. et al. Effects of dietary supplementation with gamma-oryzanol on seminal characteristics of stallions. Animal Reproduction, v.3, p.253, 2006

RODE, L.M.; COULTER, G.H.; KASTELIC, J.P. et al. Seminal quality and sperm production in beef bulls with chronic dietary
Vitamin A deficiency and subsequent re-alimentation. Theriogenology, v.43, n.7, p.1269-1277, 1995.

ROSAS FILHO, A.C.; SPERS, A.; MAZZA P.H.R. et al. Effects of l-carnitin in alimentation of stallions arabian horse on reproductive parameters. Revista Brasileira de Reprodução Animal, v.25, n.3, p.369-371, 2001.

SCAVARIELLO, E.M.; ARELLANO, D.B. $\gamma$-oryzanol: um importante componente del aceite de salvado de arroz. Archivos Latinoamericanos de Nutricion, v.48, p.7-12, 1988.

SCHMIDT, K. Der Einfuâ der Fütterung mit weissen und roten Möhren auf die spermaproduktion des Zuchtbullen. 1. Mitteilung: Quantitative Undersuchung des Spermas. Monatshefte fur Veterinarmedizin, v.8, p.47-51, 1953.

SETCHELL, B.P.; MADDOCKS, S.; BROOKS, D.E. Anatomy, vasculature, innervation, and fluids of the male reproductive tract. In: KNOBIL, E.; NEILL, J.D. (Eds.) The physiology of reproduction. New York: Raven Press, 1994, v.1. p.1063-1175.

STRADAIOLI, G.; SYLLA, L.; ZELLI, R. et al. Seminal carnitine and acetylcarnitine content and carnitine acetyltransferase activity in young Maremmano stallions. Animal Reproduction Science, v.64, n.3-4, p.233-245, 2000.

UZIEL, G.; GARAVAGLIA, B.; Di DONATO, S. Carnitine stimulation of pyruvate dehydrogenase complex (PDHC) in isolated human skeletal muscle mitochondria. Muscle \& Nerve, v.11, p.720-724, 1988.

VALE FILHO, V.R. Aspectos genéticos da subfertilidade e infertilidade dos touros. In: SIMPÓSIO NACIONAL DE REPRODUÇÃo ANIMAL, 1., 1974, Belo Horizonte. Anais... Belo Horizonte: Colégio Brasileiro de Reprodução Animal, 1974. p.67-76.

XU. Z.; GODBER, J.S. Purification and identification of components of $\gamma$-oryzanol in rice bran oil. Journal of Agricultural and Food Chemistry, v.47, p.2724-2728, 1999.

WANG, H.Y.; BAXTER Jr., C.F.; SCHULZ, H. Regulation of fatty acid beta-oxidation in rat heart mitochondria. Archives of Biochemistry and Biophysics, v.289, p.274-280, 1991.

WANG, J.Y.; LARSON, L.L.; OWEN, F.G. Effect of $\beta$-carotene supplementation on reproductive performance of dairy heifers. Theriogenology, v.18, p.461-473, 1982.

WEISS, R.R.; KLUG, E.; AHLSWEDE, L. Características do sêmen de touros jovens alimentados com carência de $\beta$-caroteno. Revista Brasileira de Reprodução Animal, v.3, p.7-16, 1979.

YOUNG, F.M.; LUDERER, W.B.; RODGERS, R.J. The antioxidant $\beta$-carotene prevents covalent cross-linking between cholesterol side-chain cleavage cytochrome P450 and its electron donor, adrenodoxin, in bovine luteal cells. Molecular and Cellular Endocrinology, v.109, p.113-118, 1995.

ZÖPFGEN, A.; PRIEM, F.; SUDHOFF, F. et al. Relationship between semen quality and the seminal plasma components carnitine, alpha-glucosidase, fructose, citrate and granulocyte elastase in infertile men compared with a normal population. Human Reproduction, v.15, p.840-845, 2000 